\title{
PEMODELAN DINAMIKA KENDARAAN DENGAN JARINGAN SYARAF TIRUAN
}

\author{
Satrio Dewanto \\ Computer Engineering Department, Faculty of Engineering, BINUS University \\ Jln. K.H. Syahdan No. 9, Palmerah, Jakarta Barat 11480 \\ satrio@binus.edu
}

\begin{abstract}
Creating autonomous vehicle that can drive without a driver is a dream of the researchers who see the application of such a system will be needed in the future. Realizing such a system requires a dynamic model of the vehicle. It may be obtained by analytical method using dynamic equations. However, this way is rather difficult to do, especially in modeling the non-linear factors caused by tires, suspension, road conditions, etc. This study, in order to avoid difficulties in the analytical method, used artificial neural networks to model the dynamic system of the autonomous vehicle. It utilized data input from the camera sensor and vehicle speed.
\end{abstract}

Keywords: autonomous vehicle, artificial neural networks, feedforward neural networks, back propagation method

\begin{abstract}
ABSTRAK
Membuat kendaraan yang dapat bergerak otonom tanpa menggunakan pengemudi merupakan impian dari para peneliti yang melihat aplikasi dari sistem seperti ini akan sangat dibutuhkan pada masa depan.Untuk mewujudkan sistem seperti ini diperlukan model dinamis kendaraan. Hal tersebut dapat diperoleh dengan metode analitis yang menggunakan persamaan dinamis. Akan tetapi, cara seperti ini agak sulit dilakukan terutama dalam memodelkan faktor non linier yang disebabkan oleh ban, suspensi, keadaan jalan, dll. Penelitian ini, untuk menghindari kesulitan dalam metode analitis, menggunakan jaringan syaraf tiruan untuk memodelkan sistem dinamis dari kendaraan otonom. Model tersebut menggunakan data input dari sensor kamera dan kecepatan kendaraan.
\end{abstract}

Kata kunci: kendaraan otonom, jaringan syaraf tiruan, jaringan syaraffeedforward, metode back propagation 


\section{PENDAHULUAN}

Penelitian di bidang kendaraan otonom telah banyak dilakukan dengan tujuan untuk menciptakan kendaraan tanpa pengemudi yang dapat mengambil keputusan sendiri dalam mengendalikan kendaraan tanpa membutuhkan campur tangan manusia. Untuk membuat model dinamis dari kendaraan otonom ini berbagai metode telah dikembangkan mulai dari penggunaan persamaan differensial (Mathworks, n.d.) yang cukup rumit, sampai dengan penggunaan jaringan syaraf tiruan dengan arsitektur yang berbeda-beda (Rivals, et al, 1994; Ghazizadeh, et al, 1996; Qiang, et al, 1999) ataupun gabungan jaringan syaraf tiruan, logika fuzzy, dan algoritma genetika (Yim \& Oh, 2004).

Penelitian ini menggunakan jaringan syaraf tiruan jenis feedforward dengan learning menggunakan metode back propagation. Untuk memodelkan kendaraan otonom, model dinamis ini akan divalidasi menggunakan data yang diperoleh dari kendaraan miniatur yang dilengkapi sensor kamera. Dengan berkembangnya zaman, teknologi yang diaplikasikan ke dalam kendaraan roda empat (mobil) makin bervariasi dan menuju tingkat kendaraan otonom, bahwa kendaraan roda empat yang dapat berjalan tanpa memerlukan pengemudi. Kendaraaan otonom merupakan kendaraan yang secara otomatis dapat mengendalikan dirinya sendiri untuk bergerak dari satu titik ke titik lainnya tanpa membutuhkan kendali dari manusia. Penelitian mengenai kendaraan otonom sudah banyak dilakukan dengan tujuan untuk merancang autodrive untuk mobil di jalan raya. Akan tetapi, sampai saat ini belum mencapai tahap yang benar-benar bisa diaplikasikan secara nyata di jalanan umum. Mobil yang otonom dapat membebaskan seseorang dari tugas mengemudi yang sangat melelahkan di jalanan yang macet atau dalam menempuh perjalanan yang jauh. Selain itu, mobil otonom juga dapat menghindari kecelakaan yang disebabkan oleh human error seperti yang sering terjadi selama ini.

Membuat suatu kendaraan otonom memerlukan pengetahuan mengenai model dinamis dari kendaraan. Sehingga, hubungan antara input yang diberikan seperti putaran kemudi mobil dan kecepatan mobil dengan output yang dihasilkan yaitu bagaimana mobil bereaksi terhadap input yang diberikan dapat diketahui. Bermacam metode untuk mendapatkan model dinamis dari kendaraan telah dilakukan. Di antaranya adalah model dinamis menggunakan persamaan dinamis yang agak sulit diterapkan dalam menangani faktor nonlinier yang dapat terjadi selama mobil berjalan.

Pengembangan berbagai metode untuk mendapatkan model dinamis masih berlangsung terus untuk mendapatkan model yang dapat mendekati keadaan nyata dari kendaraan yang akan dibuat otonom. Dalam rangka mengendalikan kendaraan yang nyata diperlukan tidak hanya simulasi tetapi juga memodelkan kendaraan dengan cepat, mudah, dan akurat.

Penelitian yang dirancang menggunakan jaringan syaraf tiruan untuk mendapatkan model dinamis dari kendaraan. Jaringan syaraf tiruan mempunyai keunggulan dalam memodelkan sistem nonlinier dan lebih mudah dibandingkan metode menggunakan persamaan dinamis, sehingga cocok untuk diaplikasikan dalam penelitian yang dilakukan. Tujuan akhir penelitian yang ingin dicapai adalah untuk mendapatkan model dinamis kendaraan yang berupa kendaraan miniatur karena terbatasnya biaya untuk menggunakan mobil yang sebenarnya.

\section{METODE}

Pemodelan dinamika kendaraan miniatur ini memerlukan data input yang berasal dari kamera dan kecepatan kendaraan. Selain itu, pemodelan memerlukan arsitektur jaringan syaraf yang digunakan dan learning method yang digunakan. Berikut dijelaskan mengenai hal-hal yang diperlukan. 


\section{Pengukuran Lateral Error dan Angle Error}

Pengenalan garis marka jalan pada penelitian dilakukan dengan menggunakan informasi citra yang ditangkap oleh kamera secara real-time. Untuk mengurangi beban perhitungan agar dapat diproses secara real-time, citra yang ditangkap kamera hanyalah citra abu-abu (grayscale) yang telah dipotong (cropped). Dengan demikian yang diproses hanyalah setengah bagian bawah dari citra awalnya.
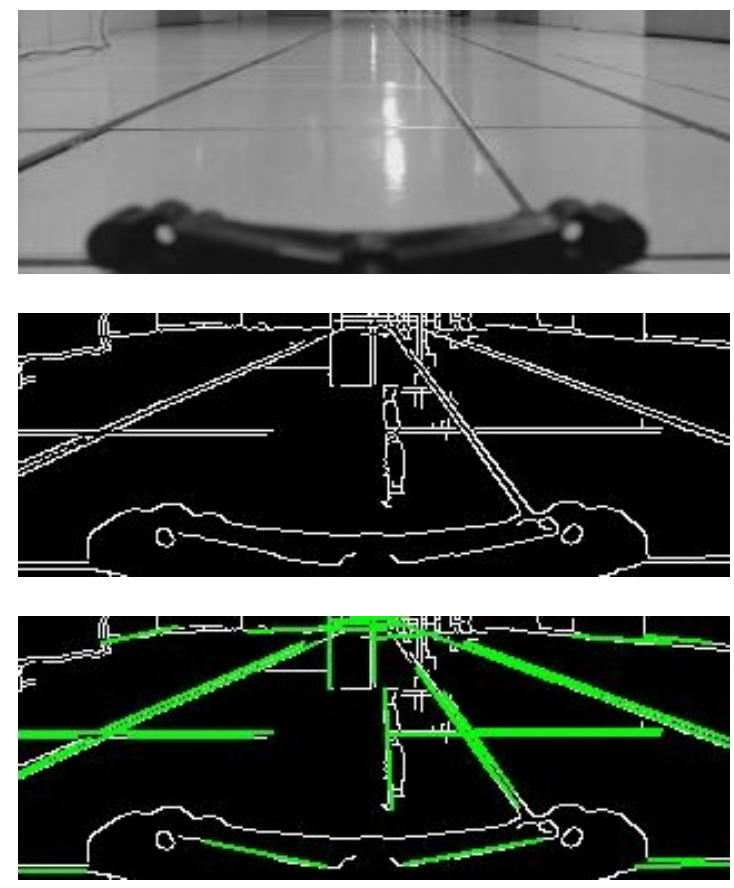

Gambar 1 Proses Pengenalan Garis

Dari pengenalan garis jika diproses lebih lanjut, dapat diketahui posisi dari kendaraan terhadap marka di kiri dan kanan jalan sehingga lateral error dapat diketahui.

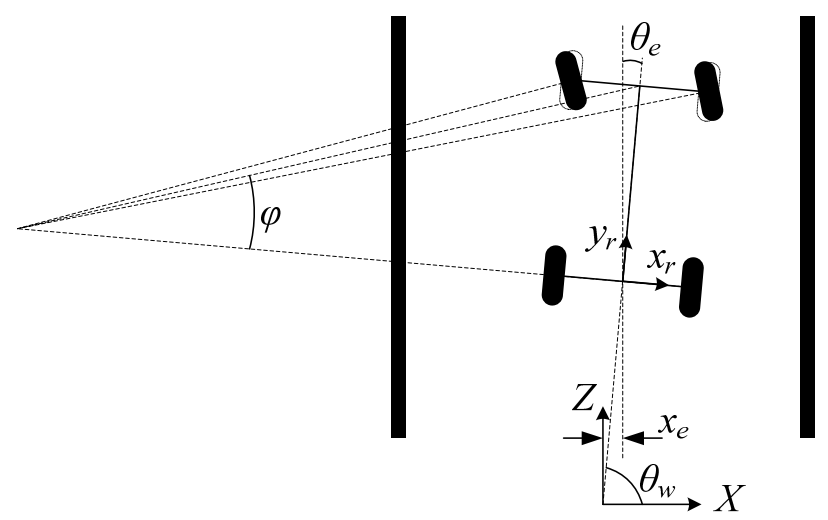

Gambar 2 Sistem Koordinat kendaraan $\left(x_{r}, y_{r}\right)$ dan bumi $\left(x_{w}, y_{w}\right)$, dengan kesalahan posisi $x_{e}$ dan kesalahan sudut $\theta_{e}$, dan sudut kemudi $\varphi$ 
Kesalahan posisi dan kesalahan sudut pada gambar tersebut dapat dihitung menggunakan data citra dari kamera, demikian pula sudut kemudi (steering angle).

\section{Arsitektur Jaringan}

Pada penelitian ini jaringan yang digunakan adalah feedforward back propagation dengan input berjumlah 4 terdiri dari lateral error, steering angle, angle error, dan kecepatan kendaraan. Sedangkan output berjumlah 2 yang merupakan prediksi nilai lateral error dan angle error pada saat berikutnya. Hidden layer menggunakan neuron sebanyak 20 buah.

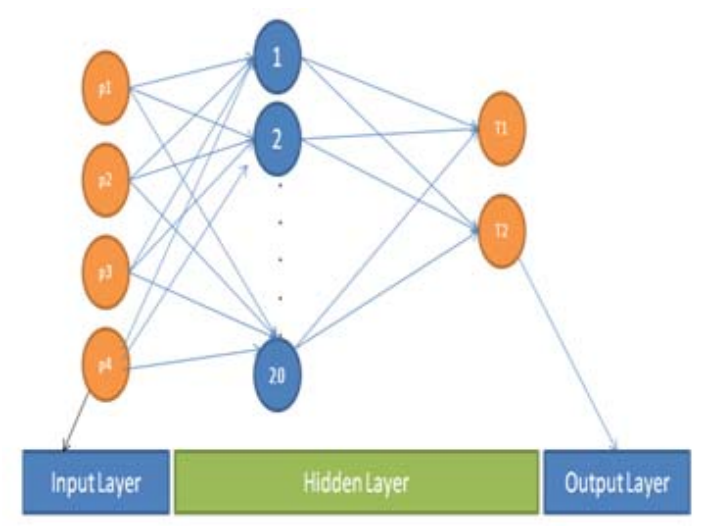

Gambar 3 Arsitektur Jaringan yang Digunakan

\section{HASIL DAN PEMBAHASAN}

Melatih jaringan syaraf tiruan yang sudah ditentukan arsitekturnya memerlukan data dari kamera dan kecepatan kendaraan miniatur. Sebagian data yang digunakan sebagai input adalah seperti Tabel 1 berikut.

Tabel 1 Data Input untuk Training

\begin{tabular}{cccc}
\hline AngleError & LatError & SteeringAngle & Speed \\
\hline 15,06720 & $-145,433$ & 1,71113 & 1450 \\
14,88330 & $-145,182$ & 1,55021 & 1450 \\
14,22980 & $-137,67$ & 1,58667 & 1450 \\
17,13220 & $-129,056$ & 5,28019 & 1450 \\
16,15890 & $-116,347$ & 5,56587 & 0 \\
17,15890 & $-115,347$ & 6,56587 & 0 \\
15,47850 & $-88,6865$ & 6,56587 & 1450 \\
16,37380 & $-96,283$ & 7,5315 & 0 \\
14,44570 & $-69,7853$ & 7,5315 & 1450 \\
14,62760 & $-74,5844$ & 7,77798 & 0 \\
15,19220 & $-75,6121$ & 8,24821 & 1450 \\
15,04720 & $-72,8593$ & 8,35605 & 1450 \\
\hline
\end{tabular}




\begin{tabular}{cccc}
\hline 14,60950 & $-71,1879$ & 8,0718 & 1450 \\
14,19240 & $-62,9867$ & 8,40793 & 1450 \\
13,47370 & $-54,652$ & 8,45467 & 1450 \\
13,66750 & $-55,1113$ & 8,60624 & 1450 \\
13,52190 & $-54,1055$ & 8,55298 & 1450 \\
10,34080 & $-25,8648$ & 8,55298 & 1450 \\
9,16059 & $-24,9922$ & 6,86539 & 0 \\
6,36998 & $-1,07883$ & 6,86539 & 1450 \\
4,98777 & 3,03553 & 5,26654 & 0 \\
3,80814 & 8,4796 & 4,58688 & 1450 \\
3,82737 & 8,47108 & 4,60533 & 1450 \\
2,37704 & 21,0973 & 4,31454 & 1450 \\
3,35694 & 9,31601 & 4,21249 & 1450 \\
2,89952 & 15,2401 & 4,29912 & 1450 \\
0,53827 & 28,2172 & 3,12964 & 1450 \\
1,05231 & 26,2721 & 3,46505 & 1450 \\
1,21473 & 26,9638 & 3,69099 & 1450 \\
\hline
\end{tabular}

Target output untuk pelatihan jaringan menggunakan data sebagaimana Tabel 2 berikut.

Tabel 2 Target Output

\begin{tabular}{cc}
\hline AngleErrorTarget & LatErrorTarget \\
\hline 14,8833 & $-145,182$ \\
14,2298 & $-137,67$ \\
17,1322 & $-129,056$ \\
16,1589 & $-116,347$ \\
17,1589 & $-115,347$ \\
15,4785 & $-88,6865$ \\
16,3738 & $-96,283$ \\
14,4457 & $-69,7853$ \\
14,6276 & $-74,5844$ \\
15,1922 & $-75,6121$ \\
15,0472 & $-72,8593$ \\
14,6095 & $-71,1879$ \\
14,1924 & $-62,9867$ \\
13,4737 & $-54,652$ \\
13,6675 & $-55,1113$ \\
13,5219 & $-54,1055$ \\
10,3408 & $-25,8648$ \\
9,16059 & $-24,9922$ \\
6,36998 & $-1,07883$ \\
4,98777 & 3,03553 \\
3,80814 & 8,4796 \\
\hline & \\
\hline
\end{tabular}




\begin{tabular}{cc}
\hline 3,82737 & 8,47108 \\
2,37704 & 21,0973 \\
3,35694 & 9,31601 \\
2,89952 & 15,2401 \\
0,53827 & 28,2172 \\
1,05231 & 26,2721 \\
1,21473 & 26,9638 \\
$-0,06838$ & 35,3408 \\
\hline
\end{tabular}

Pada pelatihan yang telah dilakukan, output error yang dirambatkan ke input untuk memperbarui bobot dan bias masih belum konvergen. Oleh karena itu, penelitian masih harus diteruskan untuk mendapatkan bobot dan bias yang sesuai.

\section{SIMPULAN}

Secara umum data input dan target output yang diperoleh dari kamera dan kecepatan kendaraan bisa dilatih untuk mendapatkan bobot dan bias yang sesuai. Hanya, sampai saat ini masih ada masalah dalam error yang tidak mau mengecil sesuai dengan yang telah ditetapkan. Perubahan dalam jumlah layer dan jumlah neuron harus dilakukan untuk mengetahui penyebab dari masalah ini. Sehingga percobaan dengan bermacam-macam arsitektur, jika memang itu penyebabnya, dapat dipecahkan. Yang menjadi masalah, data input berjumlah cukup banyak untuk melatih jaringan yang memerlukan waktu tidak sedikit. Sehingga, untuk dapat melatih jaringan ini diperlukan kesabaran.

\section{DAFTAR PUSTAKA}

Ghazizadeh, A., Fahim, M., \& El-Gindy. (1996). Neural networks representation of a vehicle model: Neuro-vehicle (NV). Int. J. Veh. Design, 17(1), 55-75.

Mathworks. (n.d.). Modeling a Vehicle Dynamics System. Diakses dari http://www.mathworks.com/help/ident/examples/modeling-a-vehicle-dynamics-system.html

Qiang, L., Huiyi, W., \& Konghui, G. (1999, Sept.). Identification and control of fourwheel-steering vehicles based on neural network. Vehicle Electronics Conf., 1, 250-253.

Rivals, I., Canas, D., Personnaz, L., \& Dreyfus, G. (1994). Modeling and control of mobile robots and intelligent vehicles by neural networks. IEEE Intelligent Vehicle Symp, June 1994, 137-142.

Yim, Y. U., \& Oh, Se-Young. (2004, Jul.). Modeling of Vehicle Dynamics From Real Vehicle Measurements Using a Neural Network With Two-Stage Hybrid Learning for Accurate LongTerm Prediction. IEEE Transactions on Vehicular Technology, 53(4), 1076-1084. 